\title{
Comparative Performance of Brinjal Hybrid in Different Seasons under Frontline Demonstration in Mohali District of Punjab
}

\author{
Munish Sharma ${ }^{1 *}$ and Priyanka Suryavanshi \\ ${ }^{1}$ Krishi Vigyan Kendra, S.A.S. Nagar (Mohali), Guru Angad Dev Veterinary and Animal \\ Sciences University, Ludhiana, Punjab, India \\ ${ }^{2}$ CSIR-Cental Institute of Medicinal \& Aromatic Plants-Lucknow, India \\ *Corresponding author
}

\section{A B S T R A C T}

\begin{tabular}{l} 
Key w o r d s \\
Brinjal, Hybrid, \\
Performance, FLD, \\
BC ratio \\
\hline Article Info \\
\hline $\begin{array}{l}\text { Accepted: } \\
\text { 17 January } 2021 \\
\text { Available Online: } \\
\text { 10 February } 2021\end{array}$ \\
\hline
\end{tabular}

Five demonstrations each were conducted during 2018-19 for two different seasons (i.e. rainy and autumn) in different villages of Mohali district of Punjab to disseminate the production technology of high yielding (672.5q/ha) Brinjal hybrid PBHR-41 and to evaluate the better growing season. Diagnostic field visits, regular surveys, farmer-scientist interactions and training programmes ensured proper seed rate, spacing, application of balanced and optimum doses of nutrients, proper weed management and timely plant protection measures. These activities ensured higher yield over local practice of cultivation in the range of 34.44-37.50 per cent. An average net profit of Rs 6,00,000/- was recorded under recommended practice while it was Rs. 3,75,000/- under farmer's practice during rainy season whereas average net profit of Rs. 7,07,500/- was recorded under recommended practice while it was Rs. 4,75,000/- under farmers' practice during autumn season. Benefit/ cost ratio ranged from 3.66 to 4.53 under demonstration in rainy and autumn season respectively while it ranged from 2.66 to 3.37 under control plots during rainy and autumn season respectively. With adoption of frontline demonstration (FLD) of proven scientific technology it is clearly interpreted that yield potential of hybrid and net returns from cultivation of brinjal could be enhanced to desired extent which in turn gives higher income to the brinjal growers.

\section{Introduction}

Brinjal (Solanum melongena Linn.) commonly known as eggplant is an important vegetable crop belonging to Solanaceae family. The crop is native of our country, so its cultivation history is quite time immemorial. It is a popular vegetable, highly cosmopolitan and is considered as poor man's crop, thereby cultivated in almost all parts of
India all round the year (Jayalakshmi and Praneetha, 2018). Despite of the favourable climatic conditions prevailing in the region the production as well as productivity of vegetables in general is not enough to cater to the growing demand. In order to meet out the demand of vegetables for the increasing population the productivity needs to be enhanced substantially through expansion in area and further increased production. 
Traditional production practices with low input supply and adoption of low yielding varieties are the reasons for the lower production (Gogoi et al., 2018). Whereas, the high yielding hybrids have many advantages over the local varieties or farmers practice. Latest research and scientific crop improvement programs have made it possible to bring out the desirable quantitative as well as qualitative traits of the parent plants in the resultant hybrids. Hybrids have many unique characteristics like vigour, trueness to type, higher yields and uniformity in addition other characteristics such as disease resistance and earliness. Uniform plant habit and maturity, coupled with uniformity in shape or size have made hybrid vegetables extremely suitable for commercial cultivation (Chinthagunti et al., 2018). Therefore there is ample scope for improvement of production and productivity of brinjal and raising the income level of the farming community. However the cultivation of the crop was not practiced and adopted by the farmers as expected. Transfer of technology is thus paramount to spread new ideas from originating sources to the end users. Brinjal is cultivated in different seasons in a year. In district Mohali mainly rainy and autumn season crops are preferred. However in the survey conducted by experts it has came in notice that a comparative study needs to be conducted to evaluate the yield and economics of both the seasons. With this objective to combat the causes of low yield and low economic returns, dissemination of recommended technology through frontline demonstration was attempted in the Mohali district for two different seasons.

\section{Materials and Methods}

\section{Experimental site, treatments and design}

Mohali district of Punjab falls under submountainous zone $\left(30.69^{\circ} \mathrm{N}\right.$ latitude, $76.72^{\circ} \mathrm{E}$ longitude) having an average altitude of $316 \mathrm{~m}$ from the sea level. The present investigation was carried out in five farmer's field each during 2018-19 for two different seasons to evaluate comparative performance of brinjal hybrid PBHR-41 for fruit yield and economics. The area under each trial was one acre. The soil of the experimental site was deep, loose and sandy loam. The trial was conducted in randomized block design (RBD) with three replications. The land was brought to a fine tilth by repeated ploughing and harrowing. The clods were broken and debris was removed. The soil was levelled and raised beds were prepared. For cultivation of crop, recommended package of practices were followed. The recommended practices included sowing of seed in the month of July for rainy season crop while in October for autumn crop. Seed rate for sowing in one acre was $300-400 \mathrm{~g}$. Spacing of $67.5 \mathrm{~cm}$ is kept between ridges and $30-45 \mathrm{~cm}$ in plants. Ten tonnes of farm yard manure, $55 \mathrm{~kg}$ of Urea, 155 $\mathrm{kg}$ of Single Super Phosphate \& $20 \mathrm{~kg}$ Muriate of Potash per acre was applied. In addition 55 $\mathrm{Kg}$ Urea was applied after two harvests. In case of local check (control plots) no change was made in the existing practices of imbalanced use of organic and inorganic fertilizers and indiscriminate use of fungicides and pesticides. Well before the demonstrations, training was imparted to the farmers. Yield data and economic parameters were collected from the demonstration plots and control plots and further cost of cultivation, net income and benefit/cost ratio were computed. The economical assessment was done as per prevailing market prices.

\section{Data collection}

Five plants were selected at random from each plot for recording yield. Based on the net plot yield, root yield per hectare was calculated and expressed in quintal (Q) per hectare. Percent increase was calculated as: Per cent increase $=($ Increase $/$ original number $)$ $\times 100$. 


\section{Economic analysis}

The cost of cultivation and gross returns were worked out by using prevailing market prices of inputs during the period of investigation. Labour and power cost for different operations such as ploughing, weeding, irrigation, sowing, bed preparation and harvesting etc. along with inputs such as seed and fertilizers were considered as per market price. Net returns were worked out using formula: Net Returns $(\mathrm{Rs} / \mathrm{ha})=$ Gross Returns (Rs/ha)-Cost of cultivation (Rs/ha). Benefitcost ratio (BCR) was worked out by using the following formula. Benefit: Cost ratio (BCR) $=$ Gross return (Rs/ha)/ Total cost of cultivation (Rs/ha).

An interview schedule was prepared and administered to the respondents and data was analyzed. Preferential ranking technique was utilized to identify the constraints faced by the farmers in brinjal cultivation. The quantification of data was done by first ranking the constraints and then calculating the rank based quotient (RBQ) as given by Sabarathanam (1998), as mentioned below:

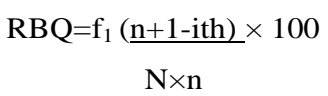

Where, $\mathrm{f}_{1=}$ Number of farmers reporting a particular problem under ith rank; $\mathrm{N}=$ number of farmers and $\mathrm{n}=$ number of problems identified.

The data output were collected from both FLD plots as well as farmer's practice plot and finally the extension gap, technology gap, technology index along with the benefit cost ratio were worked out (Samui et al., 2000) as given below

Technology Gap = Potential YieldDemonstration yield
Technology Index $=\underline{\text { Potential Yield-Demonstration yield }} \times 100$

$$
\text { Potential Yield }
$$

Extension gap $=$ demonstration yield-farmer's practice yield

Knowledge level of farmers about improved cultivation practices of the Brinjal hybrid before frontline demonstration and after implementation of frontline demonstration was measured and compared by applying dependent " $t$ " test. The selected respondents were interviewed personally with the help of a pre test and well structured interview schedule (Table 1).

Client satisfaction index was calculated by using formula as developed by Kumaran and Vijayaragavan (2005).

$\begin{aligned} \text { Client Satisfaction Index } & =\frac{\text { Individual Obtained Score }}{\text { Maximum Obtained Score }} \times 100\end{aligned}$

\section{Results and Discussion}

\section{Fruit yield}

A comparison of productivity levels between demonstrated hybrid and FP both the seasons is shown in table 2. Performance in terms of yield of Brinjal hybrid PBHR-41 was found to be substantially higher under the demonstration plots than under control plots during both the seasons (Table 2). The yield under demonstrations was $550 \mathrm{q} / \mathrm{ha}$ during rainy season whereas it was $650 \mathrm{q} / \mathrm{ha}$ during autumn season. It was, thus, evident that improved high yielding Brinjal hybrid PBHR41 performed well as comparison to FP at different seasons in the district. The productivity of local hybrids is observed to be low because of non adoption of available technologies by the farmers. Rajput et al., (2016) and Bhutada et al., 2020 have shown 
similar trend of yield results. The yield enhancement due to technological intervention was to the tune of 37.5 and 34.44 per cent over control in rainy and autumn season respectively. The cumulative effect of technological intervention over both seasons revealed an average yield of $577.5 \mathrm{q} /$ ha i.e. 35.97 per cent higher over local check. The results clearly indicated that the higher average yield in demonstration plots in both the seasons as compared to local check was due to adoption of high yielding hybrid, proper knowhow and full adoption of package of practices. Yield enhancement under recommended practice might be due to balanced nutrition as per soil test value, integrated approach and proper management practices which play a vital role in making availability of plant nutrients. Similar results were observed by Tiwari et al., (2003).

\section{Economics}

It was clearly evident from the results (Table 2) that the cost involved in the adoption of improved technology in brinjal varied in both seasons and was more profitable in autumn season. The fluctuations in yield and cost of cultivation during different seasons can be explained based on variations in microclimatic conditions and marketable price in particular season. Mukherjee (2003) also reported that depending on identification and use of farming situation specific interventions may have greater implications in enhancing systems productivity. Similar variations in results have been documented by Mishra et al., (2009) and Kumar et al., (2012) in different crops. The data clearly revealed that the net returns from the demonstration plots were substantially higher than control plots during both the seasons. An average net return was observed to be Rs 6,00,000/- in rainy season in comparison to control plot i.e. Rs 3,75,000/-. Thus on an average additional income of Rs 2,25,000/- is attributed to the technological intervention provided in demonstration plots during rainy season whereas an average net return was observed to be Rs 7,07,500/- in autumn season in comparison to control plot i.e. Rs 4,75,000/-. Thus on an average additional income of Rs. $2,32,500 /-$ is attributed to the technological intervention provided in demonstration plots during autumn season. Economic analysis revealed that benefit/cost ratio in demonstration plots was comparatively higher than control plots and this may be due to higher yield obtained under improved technologies compared to local check (farmers' practice). The highest benefit cost ratio 4.53:1 was observed in autumn season followed by 3.66 in the rainy season for demonstrations. The variation in $\mathrm{B}$ : $\mathrm{C}$ ratio could be due to price variation during the study period. The B: $\mathrm{C}$ ratio of control plots was 3.37 and 2.66 respectively during autumn and rainy season, respectively. Hence favorable $\mathrm{B}$ : $\mathrm{C}$ ratio proved the economic viability of the intervention made under demonstration and convinced the farmers on the utility of intervention. Similar findings were reported by Kushwah et al., (2017) in Pea and Sharma and Singh (2020) in Radish.

\section{Technology gap and technology index}

Considerable variations in technology gap (49-27 q/ha) reflected the influence of recommended technology used in FLDs in subsequent seasons (Table 3). These results were in close conformity with the findings of Mitra and Samajdar (2010) and Pathak (2018). The technology index showed the feasibility of the evolved technology at the farmers' fields. Lower value of technology index mean more feasibility of disseminated technology (inverse relations). The reduction in Technology index (8.19) is good indicator of increased feasibility of demonstrated technology in these demonstrations and it can be gainful proposition for the farmers of the 
district. The extension gap ranging between 60-62 q/ha during the study period emphasizes the need to educate the farmers through various means for adoption of improved agricultural production technologies to reverse the trend. Similar trends were reported by Teggelli et al., (2017).

Table.1 Details of Brinjal Hybrid grown under FLD and existing farmer's practice

\begin{tabular}{|c|c|c|c|c|}
\hline S.No. & Particulars & $\begin{array}{l}\text { Local check } \\
\text { (Farmers' } \\
\text { practice) }\end{array}$ & $\begin{array}{l}\text { Technological Intervention } \\
\text { (Demonstration) }\end{array}$ & $\begin{array}{c}\text { Technological } \\
\text { Gap }\end{array}$ \\
\hline 1 & Farming situation & Irrigated & Irrigated & No gap \\
\hline 2 & Land preparation & $\begin{array}{l}\text { Deep ploughing } \\
\text { followed by } \\
\text { rotavator }\end{array}$ & Deep ploughing followed by rotavator & No gap \\
\hline 3 & Hybrid & Farmer's Practice & PBHR-41 & Full gap $(100 \%)$ \\
\hline 4 & Sowing time & $\begin{array}{l}\text { July } \\
\text { (rainy)/October } \\
\text { (autumn) }\end{array}$ & July (rainy)/October (autumn) & No gap \\
\hline 5 & Seed rate & $500 \mathrm{~g} / \mathrm{acre}$ & $300-400 \mathrm{~g} / \mathrm{acre}$ & $\begin{array}{l}\text { More use of } \\
\text { seed }\end{array}$ \\
\hline 6 & Seed treatment & No treatment & $\begin{array}{c}\text { Seed treatment with captan } 3 g / k g \\
\text { seed }\end{array}$ & Full gap $(100 \%)$ \\
\hline 7 & Nursery bed size & Irregular & $3 \mathrm{~m} \times 1 \mathrm{~m} \times 15 \mathrm{~cm}$ & Full gap $(100 \%)$ \\
\hline 8 & Spacing & Irregular & $67.5 \times 30-45 \mathrm{~cm}$ & Full gap $(100 \%)$ \\
\hline 9 & $\begin{array}{l}\text { Manure and fertilizer } \\
\text { application }\end{array}$ & Indiscriminate use & $\begin{array}{c}10 \text { tonn FYM, } 55 \text { Kg Urea, } 155 \mathrm{~kg} \\
\text { SSP, } 20 \mathrm{Kg} \mathrm{MoP;} 55 \mathrm{Kg} \text { Urea after } \\
\text { two harvest }\end{array}$ & Full gap $(100 \%)$ \\
\hline 10 & Weed Management & Indiscriminate use & As per university recommendations & Full gap $(100 \%)$ \\
\hline 11 & Irrigation & Indiscriminate use & As per university recommendations & Full gap $(100 \%)$ \\
\hline 12 & $\begin{array}{l}\text { Plant protection } \\
\text { measures }\end{array}$ & Indiscriminate use & As per university recommendations & Full gap (100\%) \\
\hline
\end{tabular}

Table.2 Fruit yield and economics of brinjal hybrid PBHR-41 in rainy and autumn season

\begin{tabular}{|l|l|l|l|l|l|l|l|l|}
\hline Season & Variables & $\begin{array}{c}\text { Fruit } \\
\text { yield } \\
\text { (q/ha) }\end{array}$ & $\begin{array}{c}\text { \% } \\
\text { increase } \\
\text { over } \\
\text { check }\end{array}$ & $\begin{array}{c}\text { Potential } \\
\text { yield } \\
\text { (q/ha) }\end{array}$ & $\begin{array}{c}\text { Cost of } \\
\text { cultivation } \\
\text { (Rs./ha) }\end{array}$ & $\begin{array}{c}\text { Gross } \\
\text { return } \\
\text { (Rs./ha) }\end{array}$ & $\begin{array}{c}\text { Net } \\
\text { return } \\
\text { (Rs./ha) }\end{array}$ & BCR \\
\hline $\begin{array}{l}\text { Rainy } \\
\text { Season }\end{array}$ & $\begin{array}{l}\text { Farmer's } \\
\text { Practice }\end{array}$ & 400 & 37.5 & & $2,25,000$ & $6,00,000$ & $3,75,000$ & $2.66: 1$ \\
\cline { 2 - 10 } & FLD & 550 & & 672.5 & $2,25,000$ & $8,25,000$ & $6,00,000$ & $3.66: 1$ \\
\hline $\begin{array}{l}\text { Autumn } \\
\text { Season }\end{array}$ & $\begin{array}{l}\text { Farmer's } \\
\text { Practice }\end{array}$ & 450 & 34.44 & & $2,00,000$ & $6,75,000$ & $4,75,000$ & $3.37: 1$ \\
\cline { 2 - 10 } & FLD & 605 & & 672.5 & $2,00,000$ & $9,07,500$ & $7,07,500$ & $4.53: 1$ \\
\hline
\end{tabular}


Table.3 Yield gap and yield index

\begin{tabular}{|l|c|c|c|}
\hline Season & $\begin{array}{c}\text { Technology gap } \\
(\mathbf{q} / \mathbf{h a})\end{array}$ & $\begin{array}{c}\text { Extension gap } \\
(\mathbf{q} / \mathbf{h a})\end{array}$ & $\begin{array}{c}\text { Technology index } \\
(\mathbf{\%})\end{array}$ \\
\hline Rainy Season & 49 & 60 & 18.22 \\
\hline Autumn Season & 27 & 62 & 10.03 \\
\hline
\end{tabular}

Table.4 Rank based quotient obtained by the brinjal growers as respondent $(\mathrm{n}=10)$

\begin{tabular}{|l|l|c|c|}
\hline S. No. & Problem & RBQ & Rank \\
\hline $\mathbf{1}$ & Non availability of suitable hybrids & 76 & I \\
\hline $\mathbf{2}$ & Problem of Insect-Pests and weeds & 70 & II \\
\hline $\mathbf{3}$ & Low shelf life and Marketing & 62 & III \\
\hline $\mathbf{4}$ & Damage due to rains and stray/wild animals & 58 & IV \\
\hline $\mathbf{5}$ & Lack of knowhow and technical support & 34 & V \\
\hline
\end{tabular}

Knowledge gain regarding new hybrid and recommended technology among respondents

Knowledge level of respondent farmers on various aspects of improved brinjal cultivation technologies before conducting the frontline demonstrations (MS=31.5) and after frontline demonstrations (MS=73.9) was measured and compared by applying dependent "t" test. From the results of study it was noticed that mean knowledge score of farmers increased to 73.9 after successful implementation of frontline demonstrations. The mean difference was recorded to be 42.4 for brinjal growers. It was clearly evident that the increase in mean knowledge score of farmers was significantly higher as the computed value of " $t$ " (14.24) at 5 percent level of probability. It indicated that there was significant increase or gain in knowledge level of farmers that have further resulted in higher adoption of improved management practices. Similar were the findings of Kushwah et al., (2017).

\section{Technology satisfaction among respondents}

The extent of satisfaction level of farmers about performance of demonstrated hybrid was measured by Client Satisfaction Index (CSI). It was noticed that majority of farmers indicated high $(42 \%)$ to medium (30\%) level of adoption or satisfaction for improved production practices and high yielding hybrid of brinjal. However (09\%) respondents expressed lower level of satisfaction with respect to improved brinjal hybrid and production practices. The medium to higher level of satisfaction with respect to adoption of hybrid, improved production practices, farmers-scientist interactions and consultancy provided etc. indicated stronger persuasion, better linkages and keen involvement in the frontline demonstrations. The results are similar to the findings of Kushwah et al., (2017) and Singh et al., 2020.

\section{Constraints faced by farmers}

Through diagnostic field visits, surveys, farmer-scientist interactions etc. the factors contributing to low productivity like lack of suitable hybrids, lack of knowhow on improved hybrid, improper management practices, negligent plant protection measures were identified. Above stated problems could be effectively managed by usage of improved recommended technologies if used as scientific intervention. The constraints related 
to cultivation practices have been analyzed and presented in the Table 4 along with their Rank Based Quotient (RBQ) for each constraint. A perusal of data indicated that non availability of suitable hybrids, problem of insect-pests and weeds, low shelf life and marketing were found to be major constraints while damage due to rains and stray/wild animals and lack of knowhow and technical support were found to be other constraints. The view was also supported by Dhaka and Dhaka (2016).

In conclusion the results of the present study convincingly proved that the yield of Brinjal could be increased significantly with the adoption of better technological intervention. Autumn season crop is found to be better yielder and more profitable than rainy season crop in both demonstration and farmers practice. Favorable benefit cost ratios proved the economic viability of the interventions and further adoption by the farmers. The technology is suitable for enhancing the productivity of Brinjal crop and this is appropriate time for area expansion under Brinjal production in Mohali district of Punjab as the crop has market demand and favourable climatic conditions for its cultivation. The selection and adoption of appropriate hybrids under favourable climate for its growth and development can transform lives of vegetable growers.

\section{Acknowledgements}

The authors are highly thankful to the ICARATARI Zone-1, Ludhiana for providing funds to conduct this experiment.

\section{References}

Bhutada, PO., Kote, GM., Jahagirdar, JE., Kamble KR. 2020. Impact of frontline demonstration on yield of Sorghum. $J$ of Pharmacognosy and phytochemistry,
9(4):344-347.

Chinthagunti, H., Sarnaik, DA., Sharma, D., 2018. Evaluation of brinjal (Solanum melongena L.) genotypes for flowering and yield parameters. Int.J.Curr.Microbiol.App.Sci, $\quad 7(12)$ : 3101-3105.

Dhaka, SR., Dhaka, BL. 2016. Analysis of productivity constraints faced by farmers in Tonk district of Rajasthan. International Journal of Science Environment, 5(2):799-805.

Gogoi, S., Mazumder, N., Talukdar, Juri. 2018. Evaluation of brinjal varieties for yield, genetic variability and disease reaction grown as late rabi season crop in Assam. Indian J. Agric. Res, 52 (2): 191-194.

Jayalakshmi, K., Praneetha S. 2018. Evaluation of brinjal (Solanum melongena L.) local types for yield and its quality characters. International Journal of Chemical Studies, 6(3): 292297.

Kumar, A., Avasthe, RK., Lepcha, B., Mohanty, AK., Shukla, G. (2012). Impact of frontline demonstration on yield enhancement of ginger (var. Majauley) in tribal reserve biosphere of Sikkim Himalaya. J Agri Sci, 3(2): 121123.

Kumaran., Vijayaragavan. 2005. Farmer's satisfaction of agricultural extension services in an irrigated command area. Ind. J. of Ext. Edu, 41(3\&4): 8-12.

Kushwah, S., Kumari, S., Singh, RN., Singh, SR. 2017. Performance of mid duration variety of Pea (Pisum sativum L.) under FLD in Banka district of Bihar. $J$ of Krishi Vigyan, 5(2): 138-141.

Mukherjee, N. (2003). Participatory learning and action. Concept Publishing Company, New Delhi, India, pp 63- 65.

Mishra, DK., Paliwal, DK., Tailor, RS., Deshwal, AK. (2009). Impact of frontline demonstrations on yield 
enhancement of Potato. Ind. Res. J. Ext. $E d u, 9(3): 26-28$.

Mitra, B., Samajdar, T. (2010). Yield gap analysis of rapeseed- mustard through FLD. Agric. Ext. Rev, 16 (1): 16-17.

Pathak, J. (2018). Yield performance of Soybean (Glycine max L.) in Madhya Pradesh. J. Krishi Vigyan, 6(2): 253256.

Rajput, Savita., Rajput, Angad, Singh., Verma, SK., Jain, V. (2016). Impact of front line demonstration on Okra (Abelmoschus esculentus (L.). J Krishi Vigyan, 5(1): 74- 76.

Sabarathanam, VE. 1998. Manuals of field experience trainings for ARS scientists. Hyderabad: NAARM.

Samui, SK., Maitra, S., Roy, DK., Mondal, AK., Saha, D. (2000). Evaluation of frontline demonstration on ground nut (Arachis hypogeal L.) in Sundarbans. J. Ind. Soc. Coastal Agric. Res, 18 (2): 180-183.
Sharma, M., Singh, Y. 2020. Influence of frontline demonstrations on yield, yield contributing characters and economics in Radish (Raphanus sativus L.) J. of Krishi Vigyan, 8(2): 186-190

Singh, AK., Chatterjee, A., Mishra, YD., Jadon, P. 2020. Farmer's knowledge level about recommended brinjal production technology. Int.J.Curr.Microbiol.App.Sci, 9(7):242246.

Teggelli, RG., S, Suresh, SM., Zaheer, AB. (2017). Increasing yield of Chickpea (Cicer arietinum Linn.) through improved production technology in Kalaburagi District of Karnataka. $J$. Krishi Vigyan, 5(2): 83-86.

Tiwari, RB., Singh, V., Parihar, P. (2003). Role of FLD in transfer of gram production technology. Maharashtra $J$. Ext. Edu, 22 (1): 19.

\section{How to cite this article:}

Munish Sharma and Priyanka Suryavanshi. 2021. Comparative Performance of Brinjal Hybrid in Different Seasons under Frontline Demonstration in Mohali District of Punjab. Int.J.Curr.Microbiol.App.Sci. 10(02): 2194-2201. doi: https://doi.org/10.20546/ijcmas.2021.1002.261 